\title{
HUBUNGAN PRIMIGRAVIDA DENGAN KEJADIAN PREEKLAMPSIA PADA IBU HAMIL DI PUSKESMAS JAGIR SURABAYA
}

\author{
*Ani Media Harumi, Dias Kurnia Armadani' \\ *1Prodi D4 Kebidanan Sutomo Jurusan Kebidanan Poltekkes Kemenkes Surabaya, email: amediaharumi@gmail.com
}

\begin{tabular}{l} 
INFO ARTIKEL \\
\hline Riwayat Artikel: \\
Diterima: 01-06-2019 \\
Disetujui: 03-07-2019
\end{tabular}

\section{Kata Kunci:}

Primigravida

Preeklamsia

Ibu Hamil

\begin{abstract}
ABSTRAK
Abstrak: Preeklampsia merupakan masalah kesehatan yang merupakan salah satu kontributor utama morbiditas dan mortalitas pada ibu dan janin. Sampai saat ini preeklampsia belum diketahui dengan jelas penyebabnya, namun salah satu faktor risiko preeklampsia adalah primigravida. Penelitian ini bertujuan untuk mengetahui hubungan primigravida dengan kejadian preeklampsia di Puskesmas Jagir Surabaya. Jenis penelitian ini adalah survei analitik dengan rancangan cross sectional. Populasi yang digunakan adalah seluruh ibu hamil dengan usia kehamilan diatas 20 minggu pada periode bulan Januari-Desember 2017 di Puskesmas Jagir Surabaya yaitu sebanyak 278 ibu hamil, dengan sampel penelitian sebanyak 164 ibu hamil dengan teknik non probability tipe purposive sampling. Instrumen yang dipakai dalam penelitian ini adalah rekam medik. Variabel dependen adalah preeklampsia dan varibel independen adalah primigravida. Analisis dengan uji statistik chi square. Hasil penelitian ini menunjukkan bahwa ibu hamil yang mengalami preeklampsia lebih banyak terjadi pada ibu hamil primigravida yaitu $22(26,2 \%)$. Berdasarkan hasil analisis menggunakan uji statistik chi square didapatkan $\rho$-value $=0,027(\rho$-value $<0,05)$ yang artinya H1 diterima.Penelitian ini dapat disimpulkan bahwa ada hubungan antara primigravida dengan kejadian preeklampsia pada ibu hamil. Saran untuk tenaga kesehatan kususnya bidan, melakukan penyuluhan tentang preeklampsia pada ibu hamil dan pemeriksaan ANC secara rutin sangat diperlukan untuk mendeteksi dini adanya preeklampsia.
\end{abstract}

\begin{abstract}
Preeclampsia is a health issue that requires special attention because it is one of the major contributors to maternal and fetal morbidity and mortality. Until now, preeclampsia has not been clearly identified, but one of the risk factors for preeclampsia is primigravida. This study aims to determine the relationship of primigravida with the incidence of preeclampsia at Puskesmas Jagir Surabaya. This type of research is an analytical survey with cross sectional design. The population used is all pregnant women with gestational age above 20 weeks in the period of January-December 2017 at Jagir Health Center Surabaya that is as many as 278 pregnant women, with sample of study counted 164 pregnant women with technique of non probability type purposive sampling. Instrument used in this research is medical record. The dependent variable is preeclampsia and the independent variable is primigravida. Analysis with chi square statistical test.The results of this study indicate that pregnant women who experience preeklampsia more common in primigravida pregnant women is 22 (26.2\%). Based on the results of analysis using chi square statistical test obtained $\rho$-value $=0.027$ ( $\rho$-value $<0.05)$ which means HI accepted. This study can be concluded that there is a relationship between primigravida with the incidence of preeclampsia in pregnant women. Suggestions for health personnel especially midwives, counseling about preeclampsia in pregnant women and routine ANC examination is needed to detect early preeclampsia.
\end{abstract}

\section{A. LATAR BELAKANG}

Preeklampsia merupakan masalah kesehatan yang memerlukan perhatian khusus karena merupakan salah satu kontributor utama morbiditas dan mortalitas pada ibu dan janin (Pribadi, 2015). Menurut Sustainable Development Goal (SDG's) target yang dicapai sampai 2030 untuk mengurangi Angka Kematian Ibu (AKI) yaitu, dibawah 70 per 100.000 kelahiran hidup. Berdasarkan Survei Penduduk Antar Sensus (SUPAS) pada tahun 2015 angka kematian ibu di Indonesia adalah 305 kematian ibu per 100.00o kelahiran hidup. Angka ini masih jauh dari sasaran AKI pada SDG's. Kematian ibu di Indonesia masih didominasi oleh tiga penyebab utama kematian yaitu perdarahan, Hipertensi Dalam Kehamilan (HDK), dan infeksi. Namun proporsinya telah berubah, perdarahan dan infeksi cenderung mengalami penurunan sedangkan HDK proporsinya semakin meningkat. Lebih dari 25\% kematian ibu di Indonesia pada tahun 2013 disebabkan oleh HDK. (Profil Kesehatan Indonesia, 2015). Di Provinsi Jawa Timur pada tahun 2015 angka kematian ibu mencapai 89,6 per 100.000 kelahiran hidup, yang disebabkan oleh eklampsia $31 \%$, lain-lain $26 \%$, perdarahan $25 \%$, jantung $12 \%$, infeksi $6 \%$, hal ini menunjukkan bahwa penyebab tertinggi kematian pada ibu tahun 2015 adalah eklampsia yaitu sebesar 31\%. (Profil Kesehatan Provinsi Jawa Timur, 2015). Angka 
kematian ibu di Kota Surabaya tahun 2015 sebesar 87,35 per 100.00o kelahiran hidup (Profil Dinas Kesehatan Kota Surabaya, 2016). Sedangkan menurut Data Laporan Kesehatan Kota Surabaya tahun 2013 penyebab kematian ibu di Kota Surabaya tertinggi adalah preeklampsiaeklampsia sebanyak 28,59\%, HIV 10,24\%, TB Paru 6,11\%, Hepatitis 4,06\%, lain-lain kasus 12,23\%. Dari data tersebut preeklampsia merupakan penyebab tertinggi AKI di kota Surabaya (Laporan Tahunan Profil Kesehatan Rumah Sakit dr.M.Soewandhie, 2013).

Hasil dari studi pendahuluan pada tanggal 28 Oktober 2017, pada bulan Januari sampai September 2017 angka kejadian preeklampsia di tiga Puskesmas Kota Surabaya yaitu, Puskesmas Pakis sebanyak 9,7 \% dari keseluruan ibu hamil, Puskesmas Mulyorejo sebanyak 1,2 \% dari keseluruan ibu hamil, dan Puskesmas Jagir sebanyak 12,23 \% dari keseluruan ibu hamil. Dari hasil studi pendahuluhan tersebut kejadian preeklampsia tertinggi terdapat di Puskesmas Jagir. Sedangkan kejadian preeklampsia di Puskesmas Jagir 3 tahun terakhir yaitu pada tahun 2015 sebanyak 20,84\%, tahun 2016 sebanyak 24,18\%, tahun 2017 (Januari-Sebtember) sebanyak 12,23 \%. Tahun 2017 angka kejadian preeklampsia mengalami penurunan, namun angka penurunan tersebut masih belum sesuai dengan harapan dimana secara teori hanya $5-7 \%$ ibu hamil mengalami preeklampsia. Data ibu hamil primigravida di Puskesmas Jagir tahun 2017 sebanyak 56,54 \% dari keseluruan ibu hamil.

Sampai saat ini preeklampsia disebut sebagai "penyakit teori" (Sofian, 2013), karena penyebab preeklampsia hingga saat ini belum diketahui dengan jelas, banyak teori yang telah dikemukakan tentang terjadinya preeklampsia, tetapi tidak ada satupun teori yang dianggap mutlak benar. Faktor risiko yang mempengaruhi preeklampsia diantaranya primigravida, hiperplasmentosis, umur yang ekstrim, riwayat keluarga pernah preeklampsia/eklampsia, obesitas, penyakit ginjal dan hipertensi yang sudah ada sebelum hamil, obesitas (Saifuddin, 2014).

Preeklampsia dapat dialami oleh semua lapisan ibu hamil sehingga pengetahuan tentang pengolaan preeklampsia harus benar-benar dipahami oleh semua tenaga medik maupun non medik baik dipusat maupun daerah (Saifuddin, 2014). Untuk menurunkan angka kematian ibu akibat preeklampsia maka diperlukan kerja keras sehingga perlu adanya antisipasi terhadap faktor risiko yang dapat menyebabkan terjadinya preeklampsia. Khususnya pada primigravida perlunya peningkatan konseling pada ibu hamil mengenai preeklampsia agar diharapkan mampu mendeteksi dan mengantisipasi secara dini dengan menganjurkan ibu hamil memeriksakan kehamilannya secara teratur pada petugas kesehatan yang terlatih serta mencatat hasil pemeriksaan secara lengkap, sehingga dapat dilakukan tindakan pencegahan untuk mengurangi komplikasi sedini mungkin (Saifuddin, 2014).
Penelitian ini berfokus pada hubungan primigravida dengan kejadian preeklampsia pada ibu hamil di Puskesmas Jagir Surabaya.

\section{B. METODE PENELITIAN}

Penelitian ini menggunakan jenis penelitian survei analitik dengan rancangan cross sectional yang dilakukan pada bulan Maret 2018 di Puskesmas Jagir Surabaya. Populasi yang digunakan adalah seluruh ibu hamil dengan usia kehamilan diatas 20 minggu pada periode bulan Januari-Desember 2017 di Puskesmas Jagir Surabaya yaitu sebanyak 278 ibu hamil, dengan sampel penelitian sebanyak 164 ibu hamil dengan teknik non probability tipe purposive sampling. Instrumen yang dipakai dalam penelitian ini adalah rekam medik. Variabel dependen adalah preeklampsia dan varibel independen adalah primigravida. Analisis dengan uji statistik chi square.

\section{HASIL DAN PEMBAHASAN}

1. Hasil

\section{a. Primigravida Pada Ibu Hamil} TABEL 1

Distribusi Frekuensi Gravida pada Ibu Hamil di Puskesmas Jagir Surabaya Januari sampai Desember 2017

\begin{tabular}{lcc}
\hline Gravida & Frekuensi & Presentase (\%) \\
\hline Primigravida & 84 & 51,2 \\
Tidak & 80 & 48,8 \\
Jumlah & 164 & 100,0 \\
\hline
\end{tabular}

Sumber : Rekam Medik Puskesmas Jagir Tahun 2017

Berdasarkan tabel 1 dapat dijelaskan bahwa dari 164 ibu hamil sebagian besar yaitu 84 ibu hamil $(51,2 \%)$ adalah primigravida.

\section{b. Preeklampsia Pada Ibu Hamil} TABEL 2

Distribusi Frekuensi Preeklampsia pada Ibu Hamil di Puskesmas Jagir Surabaya Januari sampai

Desember 2017

\begin{tabular}{lcc}
\hline Preeklampsia & Frekuensi & Presentase (\%) \\
\hline Preeklampsia & 32 & 19,5 \\
Tidak & 132 & 80,5 \\
Jumlah & 164 & 100,0 \\
\hline
\end{tabular}

Sumber : Rekam Medik Puskesmas Jagir Tahun 2017

Berdasarkan tabel 2 dapat dijelaskan bahwa dari 164 ibu hamil sebagian kecil yaitu 32 ibu hamil (19,5\%) mengalami preeklampsia. 


\section{c. Hubungan Primigravida Dengan Kejadian Preeklampsia Pada Ibu Hamil TABEL 3}

Hubungan Primigravida dengan Kejadian Preeklampsia pada Ibu Hamil di Puskesmas Jagir Surabaya Periode Bulan Januari sampai Desember 2017

\begin{tabular}{|c|c|c|c|c|c|c|c|}
\hline \multirow{3}{*}{$\begin{array}{c}\text { Primi } \\
\text { gravida }\end{array}$} & \multicolumn{4}{|c|}{ Preeklampsia } & & & \multirow{3}{*}{$\begin{array}{c}\rho- \\
\text { valu } \\
\mathbf{e}\end{array}$} \\
\hline & \multicolumn{2}{|c|}{ Preeklampsia } & \multicolumn{2}{|c|}{ Tidak } & \multicolumn{2}{|c|}{ Jumlah } & \\
\hline & $\Sigma$ & $\%$ & $\sum$ & $\%$ & $\Sigma$ & $\%$ & \\
\hline $\begin{array}{c}\text { Primi } \\
\text { gravida }\end{array}$ & 22 & 26,2 & 62 & 73,8 & 84 & 100 & \\
\hline $\begin{array}{c}\text { Tidak } \\
\text { Primi } \\
\text { gravida }\end{array}$ & 10 & 12,5 & 70 & 87,5 & 80 & 100 & 0,027 \\
\hline Jml & 32 & 19,5 & 132 & 80,5 & 164 & 100 & \\
\hline
\end{tabular}

Sumber : Rekam Medik Puskesmas Jagir Tahun 2017

Berdasarkan tabel 3 dapat dijelaskan bahwa ibu hamil yang mengalami preeklampsia lebih banyak terjadi pada ibu hamil primigravida yaitu 22 (26,2\%). Hasil uji Chi Square Person dengan SPSS versi 21 dengan menggunakan tingkat kemaknaan ( $\alpha$ ) 0,05 didapatkan hasil $\rho$-value $=0,027(\rho$-value $<0,05)$, dengan demikian maka Ho ditolak dan H1 diterima yang artinya terdapat hubungan antara primigravida dengan kejadian preeklampsia.

\section{PEMBAHASAN}

Hasil penelitian ini menunjukkan bahwa ibu hamil di wilayah kerja Puskesmas Jagir Surabaya yang mengalami preeklampsia lebih banyak terjadi pada ibu hamil primigravida yaitu $22(26,2 \%)$.

Berdasarkan uji Chi Square Person dengan menggunakan tingkat kemaknaan $\alpha=0,05$ didapatkan hasil $\rho$-value $=0,027$ ( $\rho$-value $<0,05)$, sehingga $\mathrm{Ho}$ ditolak dan HI diterima, yang artinya ada hubungan antara primigravida dengan kejadian preeklampsia. Berdasarkan dari hasil tersebut dapat dijelaskan bahwa primigravida menjadi salah satu faktor terjadinya preeklampsia, hasil penelitian tersebut membuktikan teori yang dikemukakan oleh Sofoewan (2008), primigravida adalah salah satu faktor risiko penyebab terjadinya preeklampsia/eklampsia. Salain itu menurut Saifuddin (2014), juga menyatakan bahwa salah satu faktor risiko terjadinya preeklampsia adalah primigravida, dan primigravida mempunyai risiko lebih besar terjadi preeklampsia dibanding dengan multigravida. Berdasarkan teori imunologik yang disampaikan Sudhaberata (2007), menjelaskan tentang hubungan primigravida dengan kejadian preeklampsia, hal ini dikarenakan pada kehamilan pertama terjadi pembentukan "blocking antibodies" terhadap antigen tidak sempurna, yang makin sempurna pada kehamilan berikutnya. Selain itu menurut Cunningham (2009), preeklampsia lebih berisiko terjadi pada primigravida karena mereka akan terpapar vili korialis untuk pertama kalinya atau vili korialis dalam jumlah yang sangat berlimpah saat hamil seperti kehamilan kembar atau molahidatidosa. Selain itu mayoritas primigravida pada kehamilan minggu ke 28 - 32 minggu menunjukkan peningkatan kepekaan pembulu darah terhadap bahan vasopresor dan mengakibatkan preeklampsia. Menurut Artikasari (2009), Pada primigravida sering mengalami stres dalam menghadapi persalinan. Stres emosi yang terjadi pada primigravida menyebabkan peningkatan pelepasan corticotropic-releasing hormone $(\mathrm{CRH})$ oleh hipotalamus, yang kemudian menyebabkan peningkatan kortisol. Efek kortisol adalah mempersiapkan tubuh utuk berespon terhadap semua stresor dengan meningkatkan respon simpatis, termasuk respon yang ditunjukan untuk meningkatkan curah jantung dan mempertahankan tekanan darah. Pada wanita dengan preeklampsia/eklampsia, tidak terjadi penurunan sensitivitas terhadap vasopeptida-vasopeptida tersebut, sehingga peningkatan besar volume darah langsung meningkatkan curah jantung dan tekanan darah.

Hasil penelitian ini juga sejalan dengan jurnal penelitian yang dikemukakan oleh Denantika (2014), di RSUP Dr. M. Djamil Padang, yang berjudul "Hubungan Status Gravida dan Usia Ibu terhadap Kejadian Preeklampsia”, dari hasil analisis bivariat antara gravida dengan kejadian preeklampsia pada ibu hamil menggunakan uji Chi Square dengan tingkat kemaknaan $\alpha=0,05$ didapatkan nilai $\rho$-value $=0,036(\rho$-value $<\alpha)$ yang dapat diartikan secara statistik terdapat hubungan yang signifikan antara status gravida ibu dengan kejadian preeklampsia. Proporsi primigravida yang menderita preeklampsia 1,52 kali lebih banyak daripada primigravida yang tidak menderita preeklampsia. Hal ini menunjukkan bahwa primigravida mempunyai kecenderungan untuk mengalami preeklampsia dibandingkan dengan tidak primigravida.

Pemeriksaan antenatal yang teratur dapat menentukan deteksi dini preeklampsia dan kemudian dapat melakukan penanganan sesuai gejala. Maka harus selalu waspada apabila terdapat tanda-tanda terjadinya preklampsia dengan adanya faktor-faktor predisposisi. Walaupun preeklampsia tidak dapat dicegah sepenuhnya namun dapat dikurangi dengan memberikan penjelasan dan pengawasan yang baik pada ibu hamil (Manuaba, 2010).

\section{SIMPULAN}

Simpulan pada penelitia ini adalah sebagian besar ibu hamil di Puskesmas Jagir Surabaya adalah primigravida dan sebagian kecil ibu hamil mengalami preeklampsia sehingga ada hubungan antara primigravida dengan kejadian preeklampsia di Puskesmas Jagir Surabaya.

\section{DAFTAR RUJUKAN}

[1] Artikasari, Kurniawati .2009. Hubungan Antara Primigravida Dengan Angka2008.http://etd.eprints.ums.ac.id/406/2/j500060 
022.pdf (diakses tamggal $8 \quad$ Kejadian Preeklampsia/Eklampsia di RSUD DR. Moeardi Surakarta periode 1 januari - 31Desember November 2017).

[2] Cunningham, F. Gary. 2009. Obstetri Williams. Jakarta : EGC.

[3] Denantika, Oktaria. 2014. Hubungan Status Gravida dan Usia Ibu terhadap Kejadian Preeklampsia di RSUP Dr. M. Djamil Padang Tahun20122013.http://jurnal.fk.unand.ac.id/14054/pdf (diakses tanggal 31 Juli 2018).

[4] Manuaba I. B. G. 2010a. Ilmu Kebidanan, Penyakit Kandungan dan Keluarga Berencana. Jakarta : EGC. Pribadi Adhi., dkk. 2015. Kehamilan Risiko Tinggi Perkembangan, Implikasi Klinis, dan Kontroversi. Jakarta : Sagung Seto.

[5] Profil Kesehatan RI. 2015. Profil Kesehatan Indonesia. http://www.depkes.go.id/resources/donload/pusdatin/ profil-kesehatan indonesia/profil-kesehatan Indonesia2015.pdf (diakses tamggal 8 November 2017).

[6] Profil Kesehatan Jawa Timur. 2015. Profil Kesehatan Provensi Jawa Timur. Surabaya : Dinkes Provensi Jawa Timur.

[7] Profil Kesehatan Kota Surabaya. 2016. Profil Kesehatan Tahun 2016. Surabaya : Dinkes Kota Surabaya.

[8] Saifuddin, Abdul Bari. 2014. Panduan Praktis Pelayanan Kesehatan Maternal Neonatal. Jakarta : YBP-SP.

[9] Saifuddin, A. 2014b. Ilmu Kebidanan. Jakarta : YBPSP.

[10] Sudhaberata, K. 2007. Penanganan preeklampsia berat dan eklampsia. UPF OBGIN RSU Terakan : Indonesia.

[11] Sofian, Amru. 2013. Synopsis Obstretri.Jakarta: EGC.

[12] Sofoewan, S. 2008. Preeklampsia - eklampsia di beberapa rumah sakit di Indonesia. Majalah Obstetri Ginekologi Indonesia. Vol 27; 141-151

\section{PROFIL PENULIS UTAMA}

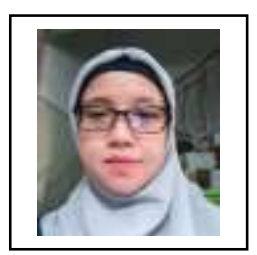

Nama : Ani Media Harumi, SST, M.Keb

Lahir di Magetan, 14 februari 1978.

Menyelesaikan pendidikan D3 Kebidanan Yarsis

Surabaya lulus tahun 2001 lalu melanjutkan kuliah di D4 Kebidanan FK Unpad lulus tahun 2006 kemudian melanjutkan kuliah di Magister Kebidanan FK Universitas Brawijaya lulus tahun 2016. 